\title{
Pengetahuan Kesehatan Jaringan Periodontal Pada Usia 11-14 Tahun Siswa/i SMPN 77 Jakarta
}

\author{
Knowledge of Periodontal Tissue Health at the Age of 11-14 Years Old Students of SMPN 77 \\ Jakarta
}

\author{
Nita Nurniza ${ }^{1 *}$, Prastiwi Setianingtyas ${ }^{1}$, Okky Marita Ardy ${ }^{1}$ \\ ${ }^{1}$ Fakultas Kedokteran Gigi, Universitas YARSI, Jakarta, Indonesia \\ *nita.nurniza@yarsi.ac.id
}

\begin{abstract}
ABSTRAK
Rongga mulut merupakan satu kesatuan sistem yang saling mempengaruhi yaitu kesehatan jaringan keras dan kesehatan jaringan lunak. Kesehatan jaringan keras terdiri dari gigi dan tulang alveolar sedangkan kesehatan jaringan lunak meliputi, mukosa rongga mulut, lidah, gingiva, ligamen periodontal, sementum. Gingiva, sementum, ligamen periodontal, dan tulang alveolar merupakan bagian dari jaringan periodontal. Jaringan periodontal dipengaruhi oleh kondisi hormonal, usia, dan penyakit sistemik. Pengetahuan mengenai kesehatan jaringan periodontal sangatlah penting terutama di usia 11-14 tahun SMPN 77 Jakarta, karena pada usia tersebut dipengaruhi oleh kondisi hormonal dan dalam tahap tumbuh kembang. Mengetahui tingkat pengetahuan siswa/i tentan pentingnya menjaga kesehatan jaringan periodontal dan kebiasaan-kebiasaan tertentu yang mempengaruhi kondisi jaringan periodontal. Diadakan pre-test sebanyak 10 soal sebelum penyuluhan dan post test dengan jumlah 10 soal setelah penyuluhan dengan soal yang sama, kemudian dilanjutkan dengan pemeriksaan gigi dan sikat gigi bersama. Tingkat pengetahuan siswa/i usia 11-14 tahun di SMPN 77 Jakarta sebanyak 169 orang mengenai kesehatan jaringan periodontal pada Pre-Test kategori baik sebesar 30\%, 45\% kategori sedang dan $25 \%$ kategori buruk. Pada Post-Test kategori baik 96\% , 3\% kategori sedang dan $1 \%$ kategori buruk. Berdasarkan hasil uji paired t-test maka terdapat perbedaan bermakna antara tingkat pengetahuan sebelum dan sesudah dilakukan edukasi dengan metode penyuluhan, yaitu p-value $<0.05$. Siswa/i SMPN 77 Jakarta usia 11-14 tahun telah memiliki tingkat pengetahuan yang tinggi mengenai pentingnya menjaga kesehatan jaringan periodontal.
\end{abstract}

Kata kunci - Usia 11-14 tahun, gingivitis, penyuluhan, sikat gigi

\begin{abstract}
The oral cavity is a unified system that influences each other, namely hard tissue health and soft tissue health. Tissue health consists of teeth and alveolar bone while soft tissue health includes oral mucosa, tongue, gingiva, periodontal ligament, cementum. The gingiva, cementum, periodontal ligament, and alveolar bone are part of the periodontal tissue. Periodontal disease tissue is influenced by hormonal, age, and systemic conditions. Knowledge of periodontal tissue health, especially at the age of 11-14 years at SMPN 77 Jakarta, because at that age it is influenced by hormonal conditions and in the stage of growth and development. knowing the level of knowledge of students about the importance of maintaining the health of periodontal tissues and certain habits that affect the condition of the periodontal tissues. There were 10 pretests about before counseling and 10 post tests after counseling with the same questions, then continued with dental examination and toothbrushing together. The level of knowledge of students aged 11-14 years at SMPN 77 Jakarta as many as 169 people about the health of periodontal tissue in the Pre-Test in the good category of 30\%, 45\% in the moderate category and $25 \%$ in the poor category. In the Post-Test $96 \%$ good category, 3\% medium category and 1\% bad category. Based on the paired ttest, there is a difference in meaning between the level of knowledge before and before education and counseling, namely p-value <0.05. Students of SMPN 77 Jakarta aged 11-14 years have a high level of knowledge about the importance of maintaining the health of periodontal tissues.
\end{abstract}

Keywords - Age 11-14 years, gingivitis, counseling 


\section{Pendahuluan}

Kesehatan manusia secara keseluruhan meliputi kesehatan tubuh dan kesehatan gigi dan mulut. Kesehatan gigi dan mulut dapat dilihat dari jaringan keras maupun jaringan lunak yang ada di dalam mulut. Jaringan keras mencakup gigi dan tulang penyangga gigi, sedangkan jaringan lunak mencakup jaringan periodontal dan mukosa dalam rongga mulut. Jaringan periodontal adalah jaringan pendukung gigi yang terdiri dari jaringan lunak dan jaringan keras. Jaringan lunak yang mendukung gigi adalah gingiva dan jaringan keras yang mendukung gigi terdiri dari sementum, ligament periodontal, tulang alveolar. ${ }^{1,2}$

Penyakit pada jaringan periodontal ada beberapa macam salah satunya ialah gingivitis. Gingivitis merupakan inflamasi pada gingiva yang meliputi jaringan gingiva sekitar gigi dan merupakan penyakit periodontal yang paling sering dijumpai baik pada usia muda maupun dewasa. Gingivitis dapat dimulai pada anak usia dini dan meningkat pada saat remaja. Pembesaran gingiva merupakan hasil dari adanya faktor iritan lokal seperti plak dan kalkulus, sedangkan perubahan hormonal yang terjadi selama masa pubertas akan memperberat pembesaran gingiva tersebut. ${ }^{1-3}$

Pada kelompok anak berumur antara 11-17 tahun, prevalensi gingivitis cukup tinggi pada anak umur 11 dan 12 tahun. Tingginya prevalensi gingivitis pada umur tersebut berkaitan dengan peningkatan hormon yang terjadi di masa pubertas. Selain faktor hormon, gingivitis juga di pengaruhi oleh kurangnya pengetahuan terhadap pemeliharaan kebersihan gigi dan mulut. Oleh karena itu perlu dilakukan penyuluhan tentang kesehatan gigi dan mulut agar pengetahuan tentang hal tersebut semakin meningkat. ${ }^{4}$

Dalam mewujudkan derajat kesehatan yang optimal, tentunya perubahan perilaku yang diharapkan setelah menerima pendidikan ataupun penyuluhan tidak dapat terjadi sekaligus. Oleh karena itu, pencapaian target penyuluhan kesehatan gigi dibagi menjadi tujuan jangka pendek, jangka menengah, dan jangka panjang.

Hasil yang diharapkan dari penyuluhan kesehatan gigi dalam jangka pendek adalah tercapainya perubahan pengetahuan dari siswa/i, adanya peningkatan pengertian, sikap, dan keterampilan yang akan mengubah perilaku siswa/i ke arah perilaku sehat, serta siswa/i dapat menjalankan perilaku sehat dalam kehidupan sehari-harinya.

Jaringan Periodontal, Gingiva, sementum, ligamen periodontal dan tulang alveolar termasuk ke dalam jaringan periodontal. Gingiva (gusi) adalah bagian mukosa di dalam rongga mulut yang mengelilingi gigi dan menutupi linggir (ridge) alveolar. Gambaran klinis gingiva gingiva normal yaitu warna gingiva umumnya berwarna merah jambu (coral pink), kontur dan ukuran gingiva sangat bervariasi yang dipengaruhi oleh bentuk dan susunan gigi geligi pada lengkungnya, konsistensi gingiva tidak dapat digerakkan dan kenyal. Tekstur permukaan attached gingiva berbintik-bintik seperti kulit jeruk. Sementum merupakan jaringan yang berfungsi untuk membantu perlekatan ligamen periodontal dengan akar gigi. Ligamen periodontal merupakan jaringan ikat yang terletak di antara akar gigi dan lamina dura atau tulang alveolar. Tulang alveolar merupakan bagian dari jaringan periodontal yang meliputi tulang maksila dan mandibula sebagai penyangga soket gigi. ${ }^{5,6}$

Gingivitis merupakan penyakit jaringan periodontal yang paling sering terjadi dan mengenai individu pada berbagai usia disebabkan akumulasi plak. Plak gigi tidak dapat dibersihkan hanya dengan berkumur ataupun semprotan air, tetapi dapat dibersihkan secara sempurna dengan cara kimia dan mekanis. Secara kimia menggunakan pasta gigi dan secara mekanis menggunakan sikat gigi. ${ }^{2,3}$

Gingivitis pubertas adalah jenis khas dari gingivitis yang berkembang pada anak-anak dan pubertas pada kelompok usia 11-14 tahun. Hal ini dipengaruhi oleh faktor hormonal yang menjadi faktor predisposisi gingivitis pubertas. Dalam hal ini terjadi ketidakseimbangan hormon dengan ditandai peningkatan hormon endokrin pada usia pubertas. Peningkatan hormon endokrin selama usia pubertas dapat menyebabkan vasodilatasi pembuluh darah dan meningkatnya kepekaan iritasi lokal, seperti biofilm plak bakteri, yang mengakibatkan gingivitis pubertas. ${ }^{7,8}$ Gambaran klinis gingivitis meliputi gingiva menjadi memerah, perubahan konsistensi gingiva, perubahan tekstur permukaan gingiva menjadi halus, mengkilap. 
Salah satu perawatan pada gingivitis yaitu dengan cara pemeliharaan yang meliputi : edukasi mengenai pentingnya menjaga kesehatan gigi dan mulut, penyikatan gigi, flossing menggunakan benang gigi/dental floss, kontrol ke dokter gigi 3 dan 6 bulan sekali. ${ }^{6-8}$

\section{Metodologi}

Penyuluhan mengenai kesehatan jaringan periodontal, materi yang akan disampaikan yaitu anatomi dan fungsi jaringan periodontal, pengertian dan tahap pembentukan plak gigi, pengertian dan etiologi penyakit jaringan periodontal, proses terjadinya penyakit periodontal, pelatihan menyikat gigi dengan benar selama 2 menit, tindakan pencegahan dini yang perlu dilakukan. Pre tes dan pos tes untuk mengetahui tingkat pengetahuan siswa/i dengan soal yang sama sebanyak 10 soal dengan pilihan jawaban setiap soal ( $\mathrm{Ya} / \mathrm{Tidak})$.

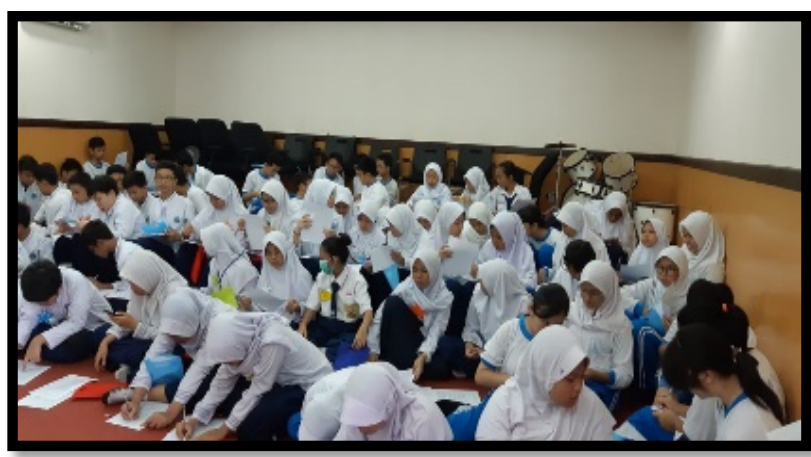

Gambar 1. Pre-Test sebelum dilakukan penyuluhan

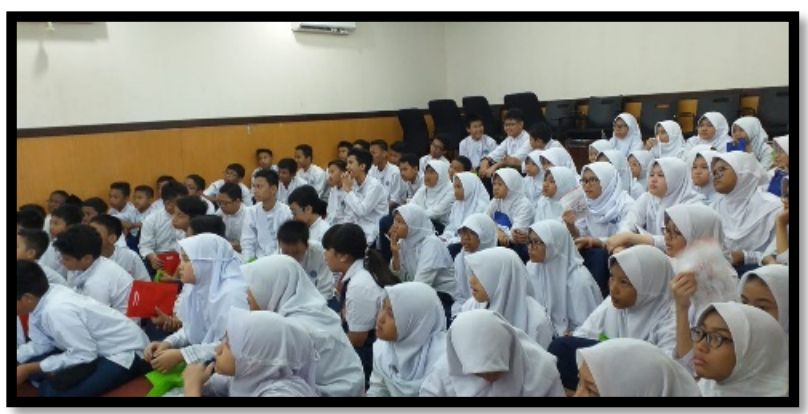

Gambar 2. Penyuluhan mengenai kesehatan jaringan periodontal pada usia pubertas 11-14 tahun

Pelatihan deteksi dini kesehatan jaringan periodontal dengan menggunakan bahan pendeteksi plak (disclosing agent). Metode yang dilakukan yaitu aplikasi bahan pendeteksi plak (disclosing agent), pemeriksaan plak gigi dengan cermin, menyikat gigi bersama, proses menyikat gigi yang tidak benar akan menunjukkan plak tetap terkumpul dan tidak hilang meski telah disikat.

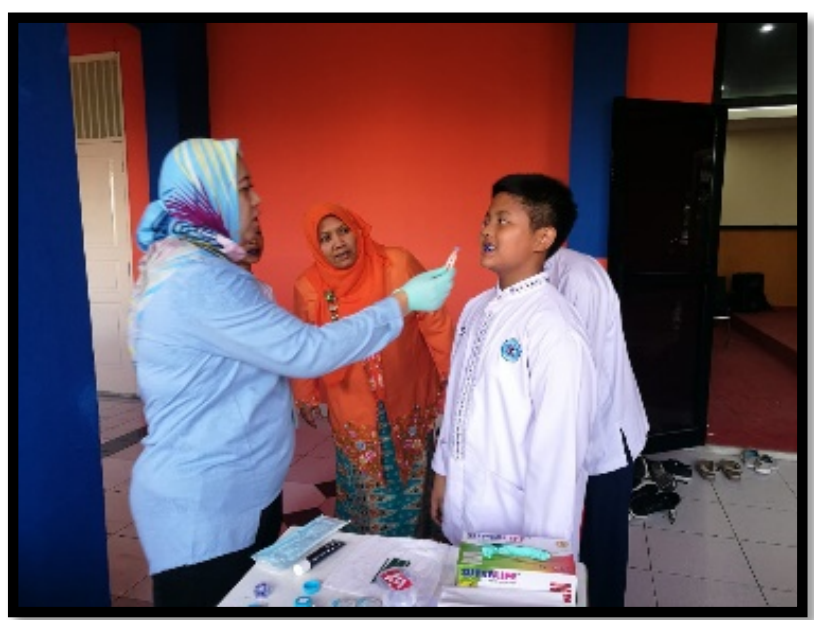

Gambar 3. Pemberian disclosing agent untuk mengetahui banyaknya plak gigi yang harus dihilangkaan saat menyikat gigi

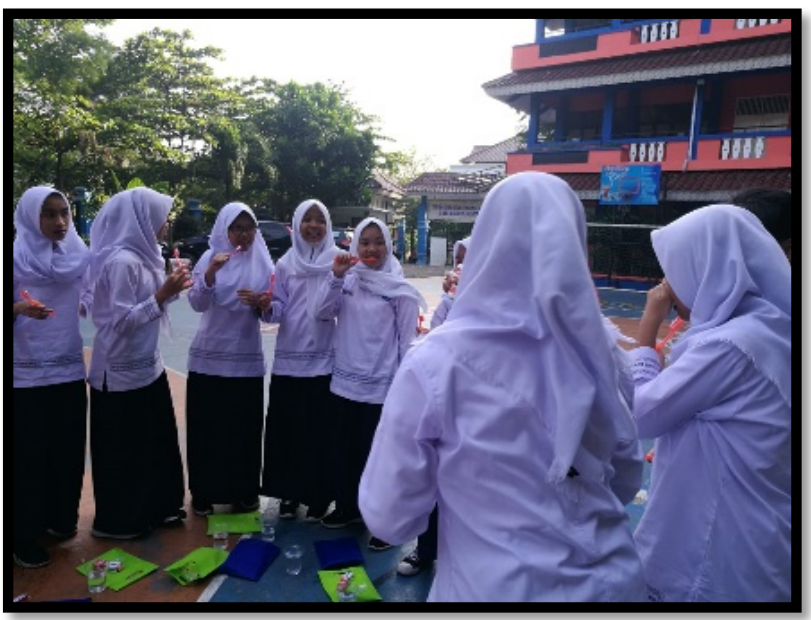

Gambar 4. Kegiatan sikat gigi bersama

Monitoring dilakukan untuk memantau keberhasilan program dilakukan 1 bulan setelah penyuluhan dan pelatihan sikat gigi bersama. Pemantauan dilakukan secara langsung melaluiwawancara dengan observasi langsung dengan siswa/i usia 11-14 tahun di SMPN 77 Jakarta. 


\section{Pembahasan}

Tingkat pengetahuan siswa/i usia 11-14 tahun di SMPN 77 Jakarta mengenai pentingnya menjaga kesehatan jaringan periodontal pada Pre-Test seperti pada diagram 1, termasuk ke dalam kategori baik sebesar 30\% , sebanyak $45 \%$ termasuk ke dalam kategori sedang dan sebanyak $25 \%$ masuk kedalam kategori buruk.

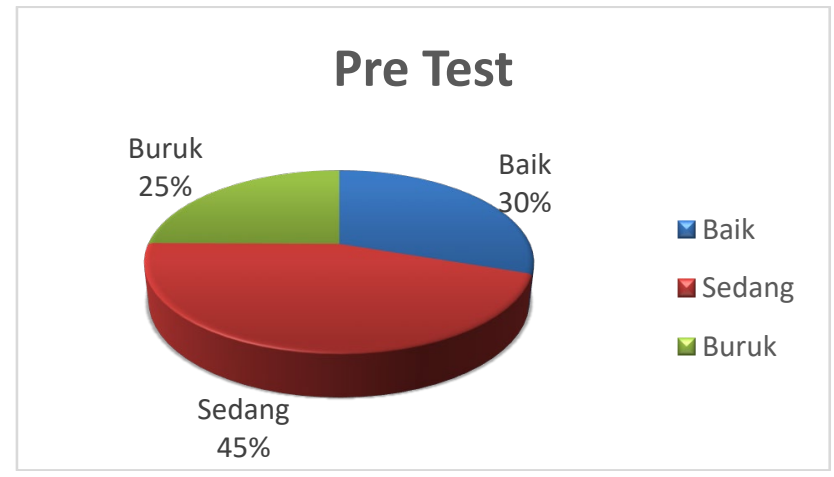

Gambar 5. Hasil Pre-Test kategori baik sebesar $30 \%$, sebanyak $45 \%$ kategori sedang dan sebanyak $25 \%$ kategori buruk.

Tingkat pengetahuan siswa/i usia 11-14 tahun di SMPN 77 Jakarta mengenai pentingnya menjaga kesehatan jaringan periodontal pada Post-Test seperti pada diagram dibawah ini, kategori baik sebesar 96\% , sebanyak 3\% masuk kedalam kategori sedang dan sebanyak $1 \%$ termasuk kedalam kategori buruk, dan tampak juga seperti diagram 2 .

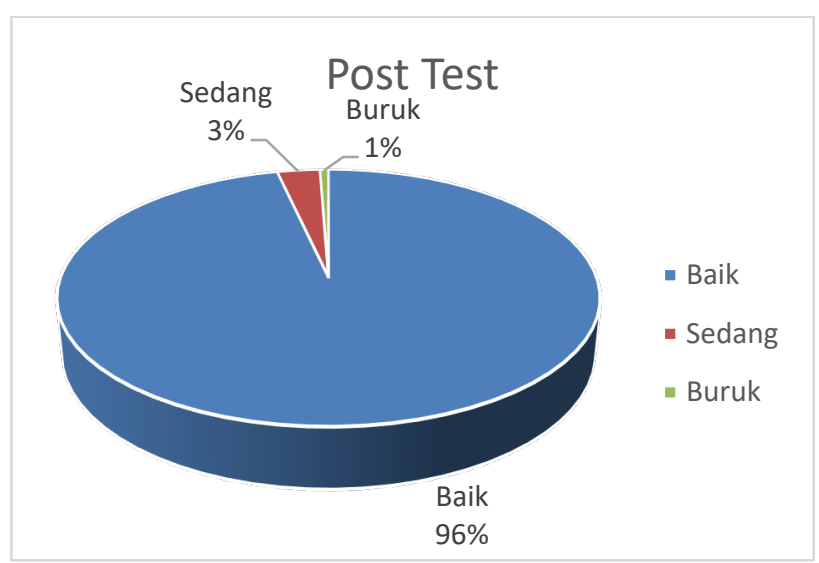

Gambar 6. Hasil Post-Test kategori baik sebesar 96\%, sebanyak 3\% kategori sedang dan sebanyak $1 \%$ kategori buruk.

Pengaruh edukasi terhadap pengetahuan siswa dilakukan uji paired t-test. Berdasarkan hasil uji paired t-test maka terdapat perbedaan bermakna antara tingkat pengetahuan sebelum dan sesudah dilakukan edukasi dengan metode penyuluhan, yaitu p-value $<0.05$.

\section{Kesimpulan}

Siswa/i SMPN 77 Jakarta usia 11-14 tahun telah memiliki tingkat pengetahuan yang tinggi mengenai pentingnya menjaga kesehatan jaringan periodontal. Pelayanan kesehatan jaringan periodontal diharapkan dilaksanakan oleh seluruh dokter gigi di Indonesia.

\section{Daftar Pustaka}

[1] Newman MG, Takei HH, Klokkevold PR, Carranza FA. Carranza's Clinical Periodontology. $11^{\text {th }}$ ed. St. Louis: Elsevier; 2012.

[2] Manson JD, Eley BM. Buku Ajar Periodonti. Alih bahasa: drg. Anastasia S. Jakarta: Penerbit Hipokrates; 1983; P.146-162.

[3] Lang NP, Schatzle MA, Loe H. 2009. Gingivitis as A Risk Factor In Periodontal Disease. J Clin Periodontal. 2009; 36(10)

[4] Cornain TZ, Suwelo IS. Gingivitis Kronis Pada Anak Umur 10 Tahun (Laporan Kasus). Jurnal Kedokteran Gigi Universitas Indonesia. Vol.3. No.2. 1995. Hal: 49-54.

[5] Hassel T, Herbert F.W. Color Atlas of Dental Hygiene Periodontology. Newyork. Thieme Inc. 2006.

[6] Newman MG, Takei HH, Klokkevold PR, Carranza FA. Carranza's Clinical Periodontology. $10^{\text {th }}$ ed. St. Louis: Elsevier Inc; 2006; P. 434-578.

[7] Novak JM, Chronic Periodontitis., in : Carranza FA. Carranza's Clinical Periodontology, 9 th edition, Philadelphia, Saunders Elsevier Inc. 1996.

[8] Rateitschak KH, Rateitschak EM, Wolf HF, Hassel TM. Color atlas of periodontology, Newyork, Thieme Inc, 3rd ed.2002. 